\title{
2. Fat tails and truncated bids in contingent valuation: an application to an endangered shorebird species ${ }^{1}$ George Parsons and Kelley Myers ${ }^{2}$
}

\section{INTRODUCTION}

Fat tails in contingent valuation (CV) refers to the phenomenon of a yesresponse function having a high and slowly declining yes-response rate at high bid levels offered in a CV survey. So, for example, a yes-response rate might hold at $20 \%$ or greater over the three or four highest bids offered in a survey. The "tails" of the yes-response function are said to be "fat" in this case. A truncated bid refers to a circumstance where high bids are not offered over a range where it appears as though the survey instrument would produce a non-zero percentage of yes responses - essentially ignoring the behavioral response to high bids or "truncating" the yes-response function.

Fat tails has been recognized and discussed in the CV literature for more than two decades (Desvousges et al., 1993). Analysts have also recognized that fat tails can create problems for parametric estimators (e.g., logit and probit), wherein the estimators are sensitive to the highest bids offered in a survey (Cooper and Loomis, 1992; Desvousges et al., 1993). In part because of this problem and in part because of the problem of negative willingness-to-pay (WTP) estimates from parametric estimators, the field has turned toward non-parametric estimators, especially the Turnbull lower bound (Kriström, 1990; Carson et al., 1994; Haab and McConnell, 1997). This chapter shows that fat tails also create problems for non-parametric estimators. The real issues presented in the data do not go away by simply changing estimators.

1 Reprinted from Ecological Economics, Vol. 129, George Parsons and Kelley Myers, "Fat tails and truncated bids in contingent valuation: an application to an endangered shorebird species," pp. 210-19, copyright 2016, with permission from Elsevier.

2 Respectively, Professor, School of Marine Science \& Policy and Department of Economics, University of Delaware; Senior Economist, Cardno, Newark, DE. 
The tail of a yes-response function is equivalent to the portion of a conventional demand curve nearest the choke price, which is where much of consumer surplus for valuation lies. For this reason, it is important to have a good measure of the yes-response function over the high-bid range; the accuracy of willingness-to-pay estimates hinges upon it. Yet, it seems common to truncate bids, forcing analysts to either ignore or to infer the yes-responses over the high-bid range from response data over low-range bids. Whether this is intentional to avoid the complications of fat tails is uncertain, but it is common.

A search over the recent $\mathrm{CV}$ literature shows that many studies have truncated yes-response functions. Table 1 is a list of $86 \mathrm{CV}$ studies along with their yes-response rate at the highest bid. This list includes studies published in eight of the leading environmental economics journals from 1990 to 2015 for which there were sufficient data to make the calculation. ${ }^{3}$ Approximately $60 \%$ of the studies have at least one scenario in their analysis where the yes-response rate at the highest bid is $20 \%$ or greater. Nearly $50 \%$ have at least one scenario above $30 \%$.

In this chapter, we explore the implication of fats tails in the context of a CV survey designed to value the protection of a relatively unknown migratory bird species whose population has declined in recent years. Our analysis is in three steps. First, we provide a review of the relevant literature. Second, we document the extent of fat tails in the response data. To do this we purposefully seek to pin down the tail of the yes-response function by offering high, what seem like unusually high, bid levels to find the choke price and explore behavioral response to high bids. We do this using an Internet-based survey and follow the standard protocol for state-of-the-art CV studies - a clear and balanced description of the good, budget reminders, follow-up certainty questions, referendum format, reinforcing consequentiality, and so forth. Third, we analyze the implications of including high bids on mean willingness to pay. We simulate this impact by calculating willingness to pay assuming different maximum bid offers and use non-parametric measures of willingness to pay throughout our analysis.

3 American Journal of Agricultural Economics (AJAE), Agricultural and Resource Economics Review (ARER), Environmental and Resource Economics (ERE), Land Economics $(L E)$, Marine Resource Economics (MRE), Journal of the Association of Environmental and Resource Economists (JAERE), Journal of Agriculture and Resource Economics (JARE), Journal of Environmental Economics and Management (JEEM). 
Table 1 Yes-response rates to highest bid in referendum-style CV studies published in eight environmental economics journals from 1990 to 2015

\begin{tabular}{|c|c|c|}
\hline $\begin{array}{l}\text { Author (Journal } \\
\text { Publication Year) }\end{array}$ & Resource Valued & $\begin{array}{l}\% \text { Yes at Highest } \\
\text { Bid Amount }{ }^{c}\end{array}$ \\
\hline Adamowicz et al. (2014) & $\begin{array}{l}\text { Heart disease risk reduction for self } \\
\text { and children }\end{array}$ & $18-32$ \\
\hline Alberini et al. (1997) & $\begin{array}{l}\text { Wetland and wildlife protection, } \\
\text { wilderness area protection, oil spill } \\
\text { prevention }\end{array}$ & $34-46(14-43)$ \\
\hline Andersson et al. (2013) & Car safety & $3-24$ \\
\hline Balistreri et al. (2001) & Insurance game & $11^{\mathrm{b}}$ \\
\hline Banzhaf et al. (2006) & $\begin{array}{l}\text { Ecological condition of Adirondack } \\
\text { Lakes }\end{array}$ & $34-52$ \\
\hline Berrens et al. (1996) & Endangered species & $8-22$ \\
\hline Berrens et al. (1997) & $\begin{array}{l}\text { Expansion of cultural center } \\
\text { programs }\end{array}$ & $13-23$ \\
\hline Blamey et al. (1999) & Salinity in soil & $17-69$ \\
\hline Blomquist et al. (2009) & Health management programs & $0-19^{b}$ \\
\hline Boman et al. (1999) & $\begin{array}{l}\text { Wolf preservation and forest } \\
\text { protection }\end{array}$ & $6-11$ \\
\hline Brown et al. (1996) & Unpaved road removal & 33 \\
\hline Brown et al. (2003) & Scholarship fund & $25-69^{b}$ \\
\hline $\begin{array}{l}\text { Cameron and Quiggin } \\
\text { (1994) }\end{array}$ & Wilderness area protection & $54(41)$ \\
\hline Carson et al. (2003) & Prevent oil spill & $34(14)$ \\
\hline Champ and Bishop (2001) & Wind-generated electricity & $31^{\mathrm{b}}$ \\
\hline Champ and Bishop (2006) & Wind-generated electricity & 7 \\
\hline Champ et al. (1997) & Unpaved road removal & 28 \\
\hline Champ et al. (2002) & Open space & $28-30$ \\
\hline Champ et al. (2009) & Whooping crane & $15-36$ \\
\hline Chien et al. (2005) & Air quality & $51-63(17-42)$ \\
\hline Cook et al. (2012) & Cholera and typhoid vaccines & $7-20$ \\
\hline $\begin{array}{l}\text { Cooper and Loomis } \\
\text { (1992) }\end{array}$ & $\begin{array}{l}\text { Hunting, wildlife viewing and risk } \\
\text { reduction }\end{array}$ & $6-42$ \\
\hline Corrigan et al. (2008) & Water quality & $32-35$ \\
\hline Desvousges et al. (2015) & Water quality & $15-45$ \\
\hline Egan et al. (2015) & Water quality & $40-42$ \\
\hline $\begin{array}{l}\text { Farmer and Lipscomb } \\
\text { (2008) }\end{array}$ & Emissions test waiver & 21 \\
\hline Frykblom (1997) & Environmental education book & $17^{b}$ \\
\hline $\begin{array}{l}\text { Frykblom and Shogren } \\
\text { (2000) }\end{array}$ & Environmental education book & $5-8^{b}$ \\
\hline Gerking et al. (2014) & Leukemia vaccine & $21-67$ \\
\hline Giraud et al. (2001) & Endangered species & 39 \\
\hline Giraud et al. (2005) & Local food product & $10-33$ \\
\hline
\end{tabular}




\section{Table 1 (continued)}

\begin{tabular}{|c|c|c|}
\hline $\begin{array}{l}\text { Author (Journal } \\
\text { Publication Year) }\end{array}$ & Resource Valued & $\begin{array}{l}\% \text { Yes at Highest } \\
\text { Bid Amount }{ }^{c}\end{array}$ \\
\hline Guria et al. (2005) & Risk reduction & $7-13$ \\
\hline $\begin{array}{l}\text { Haab and McConnell } \\
\text { (1997) }\end{array}$ & Wolf recovery, beach cleaning & $15-53$ \\
\hline $\begin{array}{l}\text { Haab and McConnell } \\
\text { (1998) }\end{array}$ & Beach cleaning & 15 \\
\hline $\begin{array}{l}\text { Hammitt and Zhou } \\
\text { (2006) }\end{array}$ & $\begin{array}{l}\text { Treatment of illnesses caused by air } \\
\text { pollutants }\end{array}$ & $8-33$ \\
\hline $\begin{array}{l}\text { Harrison and Lesley } \\
\text { (1996) }\end{array}$ & Oil spill prevention & 35 \\
\hline Herriges et al. (2010) & Water quality & 35 \\
\hline Hite et al. (2002) & Water quality & $13-14$ \\
\hline $\begin{array}{l}\text { Holmes and Kramer } \\
\text { (1995) }\end{array}$ & Forest protection & 5 \\
\hline Huth and Morgan (2011) & Cave diving & $16-19$ \\
\hline Ivehammar (2009) & Urban scenic view & $5-36$ \\
\hline Johnston (2006) & Public water supply & $33^{b}$ \\
\hline Koford et al. (2012) & Curbside recycling & 17 \\
\hline Kovacs and Larson (2008) & Open space & $12-25(6-17)$ \\
\hline $\begin{array}{l}\text { Kramer and Evan Mercer } \\
\text { (1997) }\end{array}$ & Rain forest protection & $0(0)$ \\
\hline Kriström (1990) & Forest protection & 11 \\
\hline Labao et al. (2008) & Endangered species & $9-13$ \\
\hline Landry and List (2007) & Sports memorabilia & $20-75^{b}$ \\
\hline Langford et al. (1998) & $\begin{array}{l}\text { Flood prevention and wetland } \\
\text { protection }\end{array}$ & 18 \\
\hline $\begin{array}{l}\text { Leiter and Pruckner } \\
\text { (2009) }\end{array}$ & Prevention of death in avalanche & $24-25(5-6)$ \\
\hline Leon and Arena (2012) & Reconstructing natural feature & $6-19$ \\
\hline Lindberg et al. (1997) & Traffic/noise reduction & 24 \\
\hline Longo et al. (2012) & Climate change mitigation & $45-49$ \\
\hline Longo et al. (2015) & Cutting greenhouse gas emissions & $24-58$ \\
\hline Loureiro et al. (2009) & Oil spill prevention & 15 \\
\hline Lunander (1998) & Movie preview & $11-91^{\mathrm{b}}$ \\
\hline Lusk (2003) & Genetically engineered rice & $62-72$ \\
\hline $\begin{array}{l}\text { Michael and Reiling } \\
\text { (1997) }\end{array}$ & Outdoor recreation and congestion & 0 \\
\hline Moore et al. (2011) & Water quality & 25 \\
\hline $\begin{array}{l}\text { Morrison and Brown } \\
\text { (2009) }\end{array}$ & Meal for disadvantaged children & $27-53^{\mathrm{b}}$ \\
\hline Murphy et al. (2005) & $\begin{array}{l}\text { Sign placement and endangered } \\
\text { species }\end{array}$ & $0^{\mathrm{b}}$ \\
\hline Myers et al. (2010) & Recreational bird watching & $8-13$ \\
\hline Nahuelhual et al. (2004) & Open space & $28-47$ \\
\hline
\end{tabular}




\section{Table 1 (continued)}

\begin{tabular}{llc}
\hline $\begin{array}{l}\text { Author (Journal } \\
\text { Publication Year) }\end{array}$ & Resource Valued & $\begin{array}{c}\text { \% Yes at Highest } \\
\text { Bid Amount }^{\mathrm{a}}\end{array}$ \\
\hline $\begin{array}{l}\text { Nunes and Van den Bergh } \\
\quad \text { 2004) }\end{array}$ & Algal bloom and water quality & $13(4)$ \\
Petrolia and Kim (2009) & Barrier island restoration & $18-65$ \\
Polome et al. (2006) & Natural mudflat for birds & $32-50(22-39)$ \\
Poor (1999) & Wetland preservation & $11-14(1-6)$ \\
Popp (2001) & Air and water quality & 42 \\
Ready and Hu (1995) & Preservation of horse farms & 29 \\
Ready et al. (1996) & Food-borne risk & $13-18$ \\
Reaves et al. (1999) & Red-cockaded woodpecker & 0 \\
Richardson et al. (2013) & Reduce symptom days caused by & 13 \\
& wildfires & \\
Riddel and Loomis (1998) & Spotted owl protection & $9-60$ \\
Roach et al. (2002) & Recreational moose hunting & $5-11$ \\
Ropicki et al. (2010) & Eco-label for seafood & $4-13^{\mathrm{d}}$ \\
Saz-Salazar and Garcia- & Improved waterfront area & 24 \\
$\quad$ Menendez (2001) & Speed reduction & $8-14$ \\
Scarpaet al. (2001) & Tire recycling and wildflower & 44 \\
Smith (1996) & enhancement programs & $12-13$ \\
Tuan and Navrud (2007) & Visitation to cultural heritage price & 12 \\
Wang (1997) & Environmental quality & $49(31)$ \\
Weldesilassie et al. (2009) & Improved wastewater irrigation & $19-50$ \\
Welsh and Poe (1998) & Dam releases & $36-53^{\mathrm{b}}$ \\
Whitehead et al. (2001) & Saltwater fishing & $23-38$ \\
Whitehead (2002) & Water quality, agriculture & $21-76(6-47)$ \\
Whittington (2002) & Water services & \\
Zhang et al. (2010) & Anjou pears with ethylene treatment & \\
\hline
\end{tabular}

Notes:

a. The table includes all CV studies with sufficient information to calculate yes-response rate at the highest bid from the following journals: $A J A E, A R E R, E R E, L E, M R E$, $J A E R E, J A R E, J E E M$. See footnote 3.

b. The study was done all or in part in an experimental setting but we only include hypothetical payment responses from the study.

c. For studies reporting more than one result, the range of outcomes is shown. For studies that use double-bounded dichotomous choice, we use percentage yes at initial highest bid. The numbers in parentheses are the percentage yes at the highest second bid amount and when the initial bid was the highest bid possible - or percentage responding yes - yes beginning at the highest initial bid.

d. Four percent of respondents would always pay the highest bid and $13 \%$ of respondents would sometimes pay the highest bid. 


\section{RELATED LITERATURE}

As mentioned in our introduction, several authors have called attention to the issue of fat tails in the context of estimation with a parametric model. Cooper and Loomis (1992), for example, asked, "How does bid design affect parameter estimates in a binary choice model and, in turn, mean willingness to pay?" They analyzed ten discrete-choice CV questions from three surveys (covering valuation of wildlife and hazardous waste clean up). When the top four bid levels and associated data were removed and the models re-estimated, mean willingness to pay declined on average to about $75 \%$ of its initial level. Most of the underlying data exhibited yesresponse rates above $20 \%$ at the maximum bid.

Desvousges et al. (1993) have a similar, but more dramatic, finding. In a study of migratory bird valuation, they tested the effect of dropping the highest bid on mean willingness to pay. The highest bid was $\$ 1,000$; the next highest was $\$ 250$. Both bids had yes-response rates close to $30 \%$. Estimated mean willingness to pay declined to $48 \%$ of the initial value in one case and to $34 \%$ of its initial value in another.

McFadden and Leonard (1993) found the same. In a study valuing the preservation of wilderness areas, they drop respondents who received a bid of $\$ 2,000$ (where the next highest is $\$ 200$ ) and mean willingness to pay declined to $54 \%$ of its initial value.

Brown et al. (1996) conducted a survey to value the removal of abandoned roads in the Grand Canyon to provide more wilderness area. In the course of their analysis they write, " $33 \%$ of the respondents to highest bid level (\$50) chose 'yes', providing a less-than-ideal bid distribution for the purpose of estimating WTP.” In an ensuing footnote they write:

[i]n order to provide a more accurate estimate of hypothetical WTP, in the fall of 1994 we sent the hypothetical dichotomous choice survey to a comparable sample at higher bid levels (up to \$200). However, there was no large drop in percent "yes" at these higher bid levels. Including the additional data tended to increase mean WTP compared with the estimate based only on the 1993 data. (Brown et al., 1996, p. 159; original emphasis)

Their effort to pin down the tail of the distribution fell short and their recognition that having limited response data around the highest bids as "less than ideal" is consistent with our own concern.

Haab and McConnell (2002) present a nice discussion of how binary choice models (in many forms) fit and don't fit yes-response data with truncation at high-end and low-end bids. They show the extreme sensitivity of willingness to pay to the choice of functional form and the nature of the yes-response data. In one case, the same data are shown to generate 
mean willingness-to-pay estimates of less than zero or greater than $\$ 1,000$ depending on the chosen functional form. A low yes-response rate at low bids (falling well below 100\%) and a high yes-response rate at high bids (falling well above $0 \%$ ) seem to cause a breakdown in binary choice models. In a concluding section they write, "[ $t$ ]he set of offered bids should be designed to ensure that the tails of the distribution are well defined. Undefined tails can lead to unreliable measures of central tendency of WTP."

One of Haab and McConnell's criteria for a valid measure of willingness to pay is that "[e]stimation and calculation are accomplished with no arbitrary truncation." This would seem to apply whether one is using parametric or non-parametric methods for estimating value.

The sensitivity of functional form and, in turn willingness to pay, to response data with fat tails discussed by Haab and McConnell (2002) is, no doubt, one reason we see intentional bid truncation in much of the literature. Kanninen (1993) and Kanninen and Kriström (1993) found that binary response models fit yes-response data better if the bid design concentrates bids around the expected mean and drops bids in the tails. There is no doubting their statistical finding. However, it does involve ignoring or truncating real response data over high bids in favor of predicting responses for high bids based on how people responded to lower or closer to "average" bids. If response data to high bids are truncated, binary choice models smooth out the tails in a statistically satisfying way but do so by censoring response data over the very range where we would like to know more about true behavioral response.

Herriges et al. (2010) conducted a contingent valuation survey for valuing water quality improvements on lakes in Iowa. Their focus was on exploring the implications of policy consequentiality on the results of dichotomous-choice contingent valuation surveys. In the course of their analysis they write:

[. . .]34.5\% of individuals are willing to pay the maximum bid value of $\$ 600$. As such, the posterior predictives must place considerable mass to the right of this largest bid point. The problem here is that we do not observe any outcomes to the right of the maximum bid of $\$ 600$ to inform the shape of this distribution over that region; instead, its shape is determined by estimating a mean, a variance and other statistics to purely form a sequence of binary responses, which are then used (together with our parametric assumptions) to characterize the entire WTP predictive.

This is a nice explanation of the extrapolation required to predict the shape of the yes-response surface over the truncated range. 


\section{SURVEY}

Our inquiry centers around a CV survey designed to value the protection of the red knot - a migratory bird species whose population has declined in recent years. The red knot is one of many species of shorebirds that makes a stop on the Delaware Bay during its annual 10,000-mile migration from South to North America. The stopover in May/June is timed during the horseshoe crab spawning season. The red knot relies on the horseshoe crab eggs to regain weight lost during their long-distance flight before proceeding north to breed. Over the past decade, annual counts of the red knot indicate a decline in numbers, which scientists have attributed to the overharvesting of horseshoe crabs and habitat loss. This has triggered an interest in regulations to protect the red knot such as beach/habitat preservation measures, horseshoe crab harvest limitations, and listing as an endangered species.

In our application we attempt to value the protection of the red knot via a hypothetical resource conservation program. We used an Internetbased survey and sampled households in New Jersey and Delaware. We followed standard guidelines for conducting a CV survey. ${ }^{4}$ We began with a series of introductory warm-up questions about the environment and migratory birds in the region. Then, we described the historic and current condition of the red knot using maps, pictures, and graphs. Next, we laid out a hypothetical resource conservation program to be conducted jointly by the states of New Jersey and Delaware to protect the red knot. People were then asked to vote for or against the program at some cost to their household in a referendum-style CV question (Figure $1^{5}$ ). We used a onetime tax as the payment vehicle. Each person was asked to vote once. Our survey included a budget reminder, a statement to encourage respondents to treat the survey as consequential, and a clear description of the voting mechanism. Again, see footnote 4 for a link to the entire survey. Various versions of the survey and the valuation question in particular were pretested and discussed in focus groups until we felt confident that respondents understood the resource and the vote.

The bid design used in our survey was motivated by an interest in pinning down the tails of our yes-response function. As noted earlier, this is a region of the distribution that captures those with the highest willingness to pay and, no doubt, will figure importantly in any calculation

4 See the Delaware Bay Shorebird Survey, accessed November 27, 2016 at https://delaware.qualtrics.com/SE/?SID=SV_cvXTegW9jXmVD5r.

5 Figure 1 is slightly different from the graph shown to respondents because the original figure included color that cannot be shown in this black-and-white book. 
Now, suppose the Red Knot Protection Agreement was on the ballot and that the actions in the Agreement were expected to improve the projected status of the Atlantic Red Knot in ten years from endangered to stabilized as shown below

Expected Improvement in the Status of the Atlantic Red Knot in ten Years

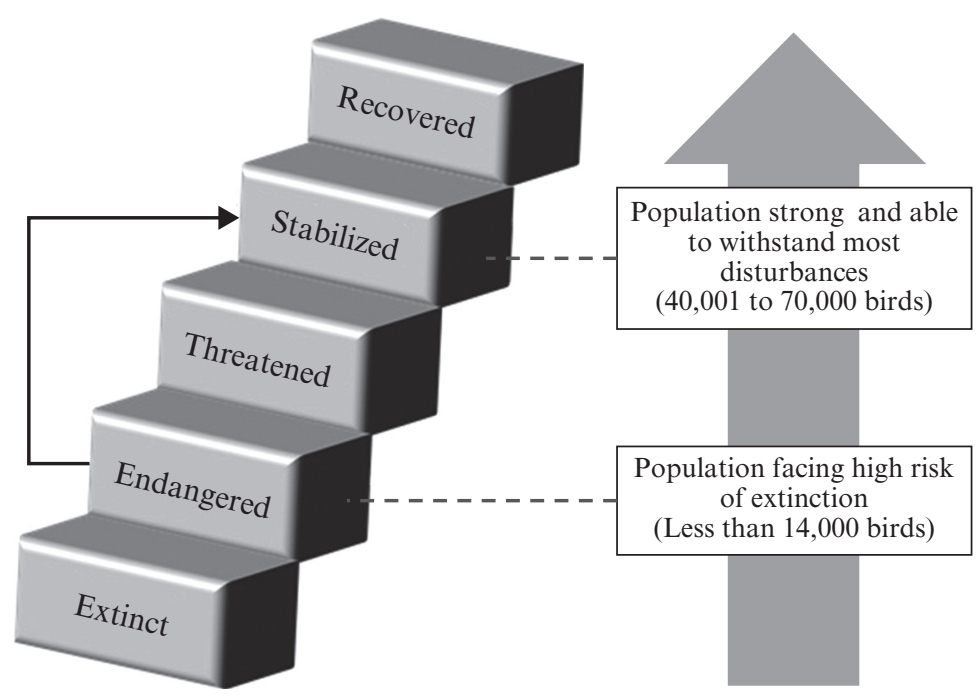

3. If the total cost to your household to finance the Agreement was a one-time payment of $\$ 5,000$, how would you vote if the Agreement were on the ballot in the next election?

Please consider your income, expenses and other possible uses of this money before you vote. Also, please remember that the results of this survey will be provided to policy makers.

I would vote for the Agreement

I I would vote against the Agreement

\section{Figure 1 Example voting question}

of mean willingness to pay for use in a benefit-cost or natural resource damage assessment. We are also interested in the implications of truncating bids at the higher end of the distribution. For these reasons, our bid design is heavy on bids at the higher end and uses sample sizes that are sufficient to accurately capture the yes-response rate to high bids. Our bids included the following one-time state tax in dollars: 25, 50, 100, 150, 200, $300,500,1,000,2,000,3,000,5,000$, and 10,000.

We drew our sample from two sources: Qualtrics and Knowledge Networks (now GfK). The Qualtrics sample is an opt-in Internet sample 
Table 2 Respondent characteristics

\begin{tabular}{lc}
\hline Variable $(\mathrm{n}=1,382)$ & Mean \\
\hline Age & 49.8 \\
Gender (1 = Male) & 0.47 \\
Income (2010) & $\$ 82,033$ \\
Education (1 = College degree or higher) & 0.54 \\
Heard of red knot (1 = Yes) & 0.12 \\
Knowledge about shorebirds (1 = Somewhat knowledgeable or & 0.28 \\
$\quad$ Very knowledgeable) & 0.17 \\
Made a trip in past five years for primary purpose of bird watching & \\
$\quad(1=$ Yes) & $<1 \%$ \\
Belongs to a bird watching group & 220.52 \\
Distance from the Delaware Bay & 35.2 \\
Number of years lived in DE or NJ & \\
\hline
\end{tabular}

that matches the New Jersey and Delaware populations along the lines of income, age, and gender. The Knowledge Networks (KN) sample is probability based and comes with probability weighting needed to adjust the sample to be representative of the underlying population. We apply these throughout our analysis. Our sample size is 1,382 and is split 775 opt-in and 607 probability-based. ${ }^{6}$ Table 2 shows some descriptive statistics for our sample.

\section{RESULTS}

In this section we present our results including the yes-response function, willingness-to-pay estimates, and some tests of the robustness of our results.

\section{Yes-response Function}

Our yes-response function is shown in Figure 2. The box-line in the figure plots the raw response data. Please note that the scale on the $\mathrm{x}$-axis is inconsistent - the same increment represents significantly more money as you move to the right. The actual shape of the curve is much longer and flatter than shown. We have a downward slope but there are some instances of non-monotonicity at bids $\$ 150, \$ 500, \$ 3,000$, and $\$ 10,000$.

6 The sample was split this way to test for differences in willingness to pay in the two samples. Since the effects of splitting the sample have no effect on our basic finding, we focus on the combined results. 


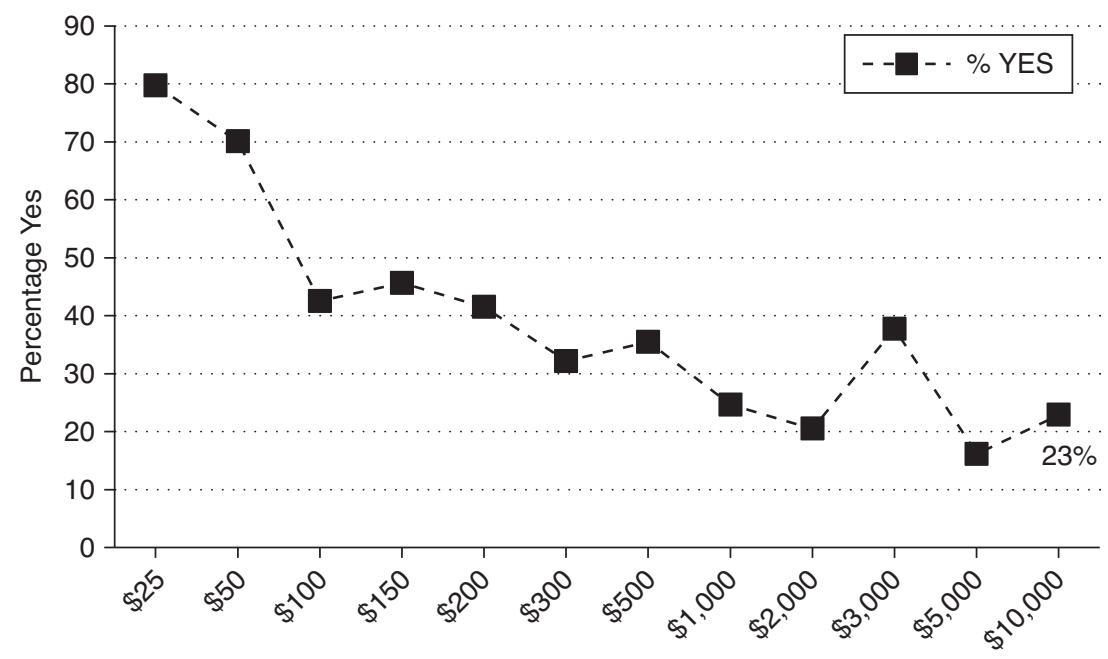

Bid Amount

Figure 2 Percentage of yes responses by bid amount

Table 3 Non-parametric estimates by bid amount

\begin{tabular}{lcccc}
\hline $\begin{array}{l}\text { High-end Bid } \\
\text { Amounts (\$) }\end{array}$ & $\begin{array}{c}\text { \% of Yes } \\
\text { Responses }\end{array}$ & Sample Size & $\begin{array}{c}\text { Lower-bound } \\
\text { Mean WTP } \\
(\$)\end{array}$ & $\begin{array}{c}\text { \% of Mean } \\
\text { Accounted for by } \\
\text { Highest Bid }\end{array}$ \\
\hline 200 & 41 & 80 & 102 & 91 \\
300 & 32 & 90 & 134 & 76 \\
500 & 35 & 148 & 204 & 81 \\
1,000 & 25 & 132 & 327 & 84 \\
2,000 & 21 & 148 & 533 & 78 \\
3,000 & 38 & 144 & 897 & 91 \\
5,000 & 16 & 143 & 1,220 & 69 \\
10,000 & 23 & 136 & 2,254 & 84 \\
\hline
\end{tabular}

Table 3 shows the yes-response rates for bids $\$ 200$ to $\$ 10,000$ along with other data. At bids between $\$ 200$ and $\$ 500$, about $30-40 \%$ of the sample are voting yes for red knot protection. At bids over $\$ 1,000$, about $20-25 \%$ vote yes. At $\$ 10,000$, our highest bid, we still have $23 \%$ of the sample voting yes. ${ }^{7}$ Obviously, our response data exhibit fat tails.

7 Every yes-response percentage is statistically significantly different from zero at the $99 \%$ level of confidence. 


\section{Willingness to Pay Estimates}

Table 3 also presents our non-parametric mean estimates of willingness to pay assuming different maximum bids. For example, if we had used $\$ 2,000$ as our maximum bid, mean willingness to pay would have been $\$ 533$ per household using a lower-bound non-parametric estimate. We used Vaughn and Rodriguez's (2001) lower-bound measure for this calculation. The estimate applies the yes-response probability over a given interval to the lower bound of that interval in each instance (e.g., if our smoothed function places 5\% of the sample between $\$ 200$ and $\$ 300$, all 5\% are assumed to have a willingness to pay of $\$ 200$, even though some may be as high as \$299). The formula for the lower bound (see Vaughn and Rodriguez, 2001, Table 1) is:

$$
W T P_{L B}=\sum_{j=1}^{M+1} b_{j-1} \cdot p_{j}
$$

where $p_{j}$ is the probability density in bid group $j ; b_{j}$ is one of $\mathbf{M}$ bid offers; $p_{j}=F_{j}-F_{j-1}$, where $F_{j}=N_{j} /\left(N_{j}+Y_{j}\right)$ is the cumulative density for bid group $j ; N_{j}$ is the number of no votes in bid group $j$, and $Y_{j}$ is the number of yes votes in bid group $j .{ }^{8}$ (Note: $b_{0}=0, F_{0}=0, F_{M+1}=100$.)

Table 3 shows the dramatic effect of bid truncation on willingness to pay. If we had used $\$ 200$ as a maximum bid instead of $\$ 10,000$, our lowerbound mean willingness to pay would have been $\$ 102$ per household. This ignores the density under the yes-response function in Figure 2 for bids greater than $\$ 200$ or what is essentially the demand curve over the high price range. Lower-bound mean willingness to pay doubles (versus \$200) if $\$ 500$ is used as the maximum bid, triples if $\$ 1,000$ is used, increases ninefold if $\$ 3,000$ is used, and finally jumps as high as 20 times if $\$ 10,000$ is used. 9,10

To further appreciate the importance of the maximum bid selection, we have calculated the percentage of the lower-bound mean willingness to pay accounted for by the highest bid, which is also reported in Table 3 . Think

8 This computation assumes no folding back of probabilities due to nonmonotonicity. See Vaughn and Rodriguez (2001) or Haab and McConnell (2002) for folding back.

9 We also calculated intermediate values of willingness to pay following Vaughn and Rodriguez (2001). As expected, these gave us even larger willingness-to-pay estimates. At $\$ 200$, willingness to pay is $\$ 331$ and at $\$ 10,000$ it is $\$ 2,706$. The computed choke price in these cases played a large role in the final values.

10 It is interesting to note that the median value (\$89) does not change with the maximum bid. This may have implications for voting outcomes but it is not useful in a benefit-cost or damage assessment setting where means are needed. 
of adding up the bid increments in the non-parametric calculation in equation (1). The increment over the final bid is the share attributed to the highest bid offer. For our lower-bound measure of willingness to pay, that share is $H B_{\text {share }}=b_{M p M+1} / \mathrm{WTPLB}$, where $b_{M}$ is the highest bid. As shown the share ranges from about 69 to $91 \%$ of the total value. In effect, a high yes-response rate at the highest bid places enormous weight on that bid and hence accounts for a large share of the value. This result emphasizes the importance of good resolution on the upper end of the distribution. If one believes the estimates, this result also suggests that concentrating bids near the upper end of the tail where most of the willingness to pay is located is a sensible research strategy, contrary to the current practice of truncating this range. Concentrating bids at the high end of the tail also helps detect hypothetical bias in willingness to pay.

Finally, consider the sheer size of the mean bids when high bid levels are introduced. The mean (lower-bound) willingness to pay is $\$ 2,254$ when the highest bid is used. Keep in mind that only $12 \%$ of the population was aware of the red knot before taking the survey. One would expect a greater awareness of a resource worth thousands of dollars per household. These estimates give an aggregate value for the states of New Jersey and Delaware over $\$ 15$ billion. Since the contingent valuation question has the bird population increasing by 16,000 to 36,000 birds, the values translate to about $\$ 400,000-900,000$ per "sustained" bird. For more perspective, the average household contributes about $\$ 4$ to wildlife conservation programs. Although suffering from free-riding effects (and hence understating full value), these include all wildlife, well beyond our single bird species. For all environmental causes this value is about $\$ 18$ per household. ${ }^{11} \mathrm{We}$ made a similar calculation for environmental outlays per household in the United States and estimate that the average household implicitly pays about $\$ 2,600$. Again, this is for all federal and state environmental protection, fish and wildlife management, forest management, and several other "environmental" categories. ${ }^{12}$ Viewed next to these numbers, our estimates are difficult to accept as true resource values.

We see fat tails as a manifestation of hypothetical bias, which has been an issue with contingent valuation response data since its inception people not taking the survey seriously and not treating the willingnessto-pay question as a real trade-off (with money) as intended. Seeing fat tails this way implies that it is a symptom of a larger problem present in

11 These calculations were made using aggregate data from Charity Navigator (charitynavigator.org).

12 These calculations were made using budgets from environmental-related agencies and include a Resources for the Future estimate of regulatory compliance cost ( $2 \%$ of GDP), which is the highest component of the value (Morgenstern et al., 1998). 
contingent valuation data and not a separate, isolated issue to be dealt with on its own. Fat tails is consistent with many of the issues surrounding CV: yea-saying, treating the survey as hypothetical, anchoring, voting simply to show support for a program, treating the good as some broader environmental purpose, and so on. All of these it would seem could generate fat-tailed response data. Boyle (2003), for example, sees the issue of fat tails as a manifestation of yea-saying:

Another problem has been termed "yea saying," which is the propensity of some respondents to answer yes to any bid amount presented to them. Here it seems that bid amounts are not acting as a quality or price cue. The manifestation of this problem has been the so-called "fat-tails" problem, with as much as $30 \%$ of a sample answering yes to any bid amount. When the inverse of the empirical cumulative distribution function (CDF) asymptotically approaches 0.30 , rather than 0.00 , the result is an extremely large estimate of central tendency with a large standard error. (Boyle, 2003, p. 140) [Citations within the quote have been removed.]

Responses to extreme (high) bid offers in a CV survey are in a sense a test of the method itself - a way of revealing the reasonableness of responses that cannot be seen as easily over lower bid offers. If a survey is valid, one would expect a reasonable yes-response rate over the higher-end bids and an ability to pin down the tail of the distribution with plausible mean willingness-to-pay estimates. If not, something must be amiss and explanations are needed.

\section{Adjusting for Hypothetical Bias}

We adjusted our yes-response function using a follow-up certainty question. This is one of several approaches commonly used to account for hypothetical bias (Champ et al., 2009). Immediately following our CV referendum question we asked respondents:

On a scale of 1 to 10, where 1 means "very uncertain" and 10 means "very certain," how certain are you that this is how you would vote if the Red Knot Protection Agreement were actually on the ballot?

Please recall that you voted for/against the Agreement at a one-time cost to your household of [respondent's bid offer].

We used this variable to weight our response data. A person reporting a certainty level of 10 (very certain of their response) was assigned a weight of 1.0; a person with a certainty level of 9 was assigned a weight of 0.9 and 


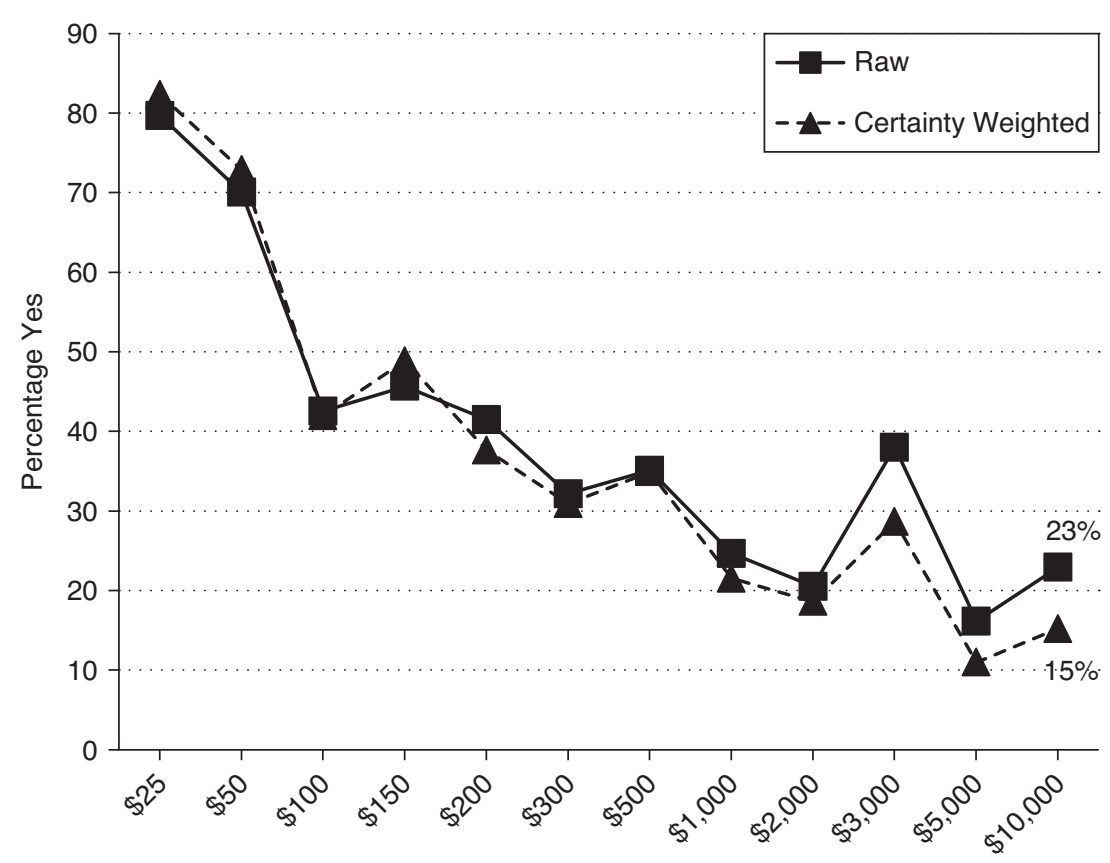

Bid Amount

Figure 3 Comparison of percentage of yes responses vs responses adjusted for certainty

so forth. In this way, responses with greater certainty were given a higher weight.

Figure 3 shows the weighted and unweighted yes-response functions. The weighted function is about the same as the unweighted function until the bid reaches $\$ 2,000$. From there and up the weighted function has a lower tail. Yes responders tend to have a lower certainty level over the higher bids and this pulls the tail down. At $\$ 10,000$, for example, the percentage voting yes declines from $23 \%$ to $15 \%$ of the sample.

Table 4 shows the adjusted willingness-to-pay estimates. In line with the yes-response functions, there is little change in the lower-bound willingness-to-pay estimates for the weighted response data until the bid levels of $\$ 2,000$ and above are reached. At $\$ 10,000$ mean willingness to pay using the lower-bound data is reduced from $\$ 2,254$ to $\$ 1,030$. Still, the levels of willingness to pay, even after certainty adjustment, are high. 
Table 4 Non-parametric estimates by bid amount and adjusted for
hypothetical bias

\begin{tabular}{lcccc}
\hline $\begin{array}{l}\text { High-end Bid } \\
\text { Amounts (\$) }\end{array}$ & $\begin{array}{c}\text { \% of Yes } \\
\text { Responses }\end{array}$ & Sample Size & $\begin{array}{c}\text { Lower-bound } \\
\text { Mean WTP (\$) }\end{array}$ & $\begin{array}{c}\text { \% of Mean } \\
\text { Accounted for } \\
\text { by Highest Bid }\end{array}$ \\
\hline 200 & 38 & 58 & 103 & 81 \\
300 & 31 & 65 & 134 & 75 \\
500 & 35 & 117 & 204 & 84 \\
1,000 & 22 & 105 & 311 & 71 \\
2,000 & 19 & 113 & 497 & 84 \\
3,000 & 29 & 102 & 774 & 83 \\
5,000 & 11 & 126 & 993 & 56 \\
10,000 & 15 & 98 & 1,030 & 71 \\
\hline
\end{tabular}

\section{Belief in Bid Values}

Respondents are told that if more than half of the population votes in favor of the Red Knot Protection Agreement their household will pay a tax of \$X into a Red Knot Protection Fund and the program described will be implemented. Respondents may or may not believe the $\$ X$ presented in the survey. People may use another amount they find more believable. For example, people may make a mental calculation of what a reasonable per household cost for the program is and adjust the amount given in the survey up or down accordingly. Or, people may look for some historical context of what a realistic tax in their state might be for the program and use that expected level. In our case, particularly with regard to the high bid levels shown, people may not believe that a tax for a bird protection program would ever reach such heights. Similarly, people may be skeptical of a low tax on the valuation question, thinking in the real world that the cost the government will incur to achieve success will actually be higher. Whether respondents accept the bid they are told and then vote based on that bid is simply unknown. To explore this issue, we asked the following follow-up question:

When you voted, did you think that your household would actually end up paying the tax amount stated, or did you think you would pay more or less than that amount?

Table 5 shows the response frequencies for this question. About $17 \%$ of all voters thought they would have to pay less than the amount stated in the survey and about $21 \%$ thought they would pay more. Figure 4 shows how the sample responded by bid levels. As the bid level increases more people 
Table 5 Responses to follow-up question about the tax amount in vote

\begin{tabular}{|c|c|c|c|}
\hline \multirow{2}{*}{$\begin{array}{l}\text { When you voted, did you think that } \\
\text { your household would actually end up } \\
\text { paying the tax amount stated, or did } \\
\text { you think that your household would } \\
\text { pay more or less than that amount? }\end{array}$} & \multicolumn{3}{|c|}{ Percentage of Total } \\
\hline & $\begin{array}{c}\text { Yes voters } \\
\mathrm{N}=493\end{array}$ & $\begin{array}{c}\text { No voters } \\
\mathrm{N}=879\end{array}$ & $\begin{array}{c}\text { Entire sample } \\
\mathrm{N}=1,372\end{array}$ \\
\hline The amount stated & 32 & 42 & 39 \\
\hline More than the amount stated & 24 & 19 & 21 \\
\hline Less than the amount stated & 21 & 15 & 17 \\
\hline Unsure & 23 & 24 & 24 \\
\hline
\end{tabular}

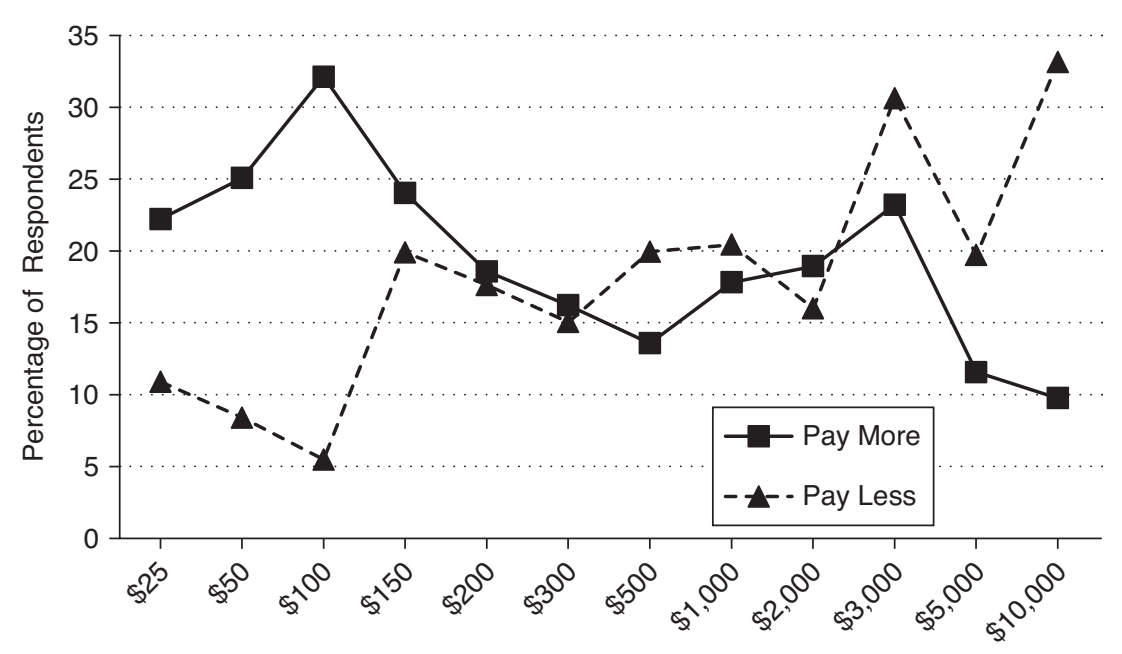

Figure 4 Percentage of respondents who believed they would pay more or pay less than offered bid amount

believe that they would pay less than the stated amount. This suggests that people who received high bids may simply reject the plausibility of the bid and insert one of their own. At \$10,000, for example, about 33\% of the sample believed that they would actually pay less than the amount stated. At $\$ 25$ only $11 \%$ believe they would pay less. In contrast, as the bid increases the share of people saying they would pay more declines. Surprisingly, even at the highest bid levels $10 \%$ believed they would pay more and most believed the stated amount.

Following this question, we asked the respondents who believed that they would pay something other than the stated amount in the survey 


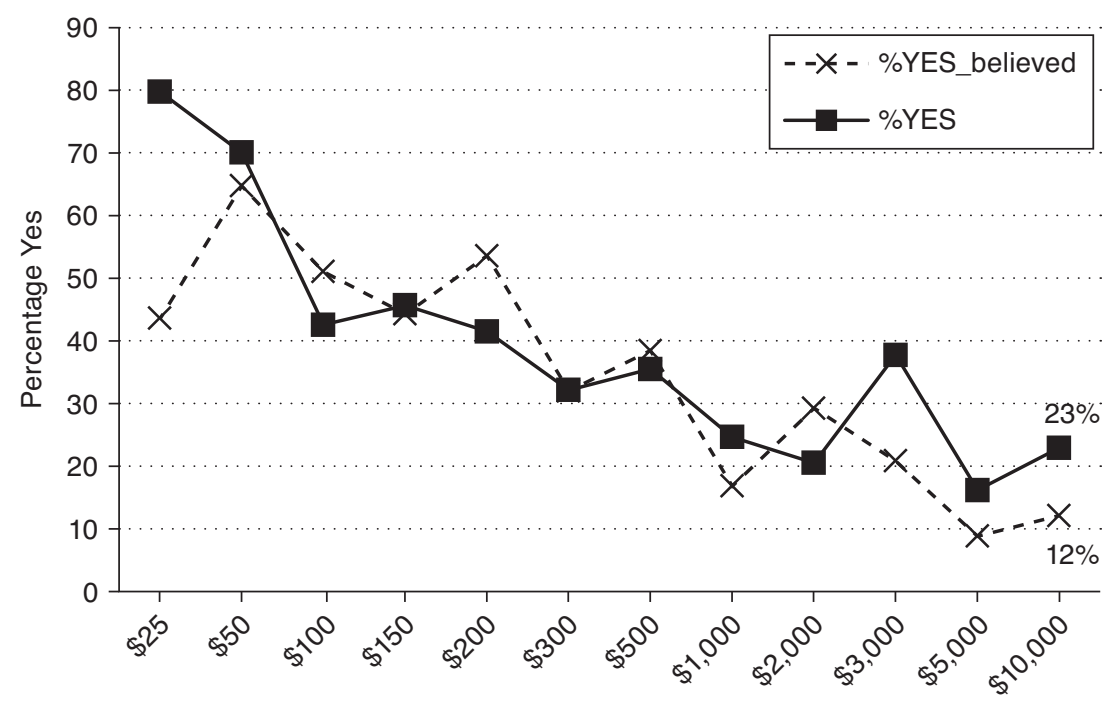

Bid Amount

Figure 5 Comparison of percentage of yes responses vs responses adjusted for "believed" bid amount

(about 38\% of the sample) to report the amount they actually thought they would pay. We used this amount to recode the data and reconfigure the yesresponse function. For example, if someone was asked if they would vote yes at $\$ 5,000$ but believed they would actually pay only $\$ 100$, we recoded this respondent as a yes at $\$ 100$. This presumes that the person voted using $\$ 100$ as the tax. It is entirely possible that a person may have voted using the amount stated even if they found the amount implausible. Our adjusted yes-response curve is shown in Figure 5. Our mean willingness-to-pay estimates using the same non-parametric procedure reported earlier are shown in Table 6. Again, we report the values assuming truncation at each bid shown. The estimates fall versus the raw data as expected. The decline over the higher-end bids is largest. At $\$ 10,000$, for example, the mean lowerbound WTP declines from \$2,254 using the raw data to \$1,508 using the newly configured data. But again, the values after adjusting are still high.

\section{Follow-up Questions}

Finally, we included a number of other follow-up questions to explore respondent behavior at high bids. The results are mixed on explaining why the tail of the yes-response function is fat. On one hand, we found 
Table 6 Non-parametric estimates by bid amount and adjusted for believed bid

\begin{tabular}{lcccc}
\hline $\begin{array}{l}\text { High-end Bid } \\
\text { Amounts (\$) }\end{array}$ & $\begin{array}{c}\text { \% of Yes } \\
\text { Responses }\end{array}$ & Sample Size & $\begin{array}{c}\text { Lower-bound } \\
\text { Mean WTP (\$) }\end{array}$ & $\begin{array}{c}\text { \% of Mean } \\
\text { Accounted for by } \\
\text { Highest Bid }\end{array}$ \\
\hline 200 & 54 & 104 & 103 & 98 \\
300 & 32 & 93 & 135 & 75 \\
500 & 38 & 153 & 211 & 85 \\
1,000 & 17 & 120 & 295 & 59 \\
2,000 & 29 & 131 & 560 & 78 \\
3,000 & 21 & 87 & 779 & 80 \\
5,000 & 9 & 138 & 955 & 46 \\
10,000 & 12 & 124 & 1,508 & 60 \\
\hline
\end{tabular}

a tendency of respondents to mentally scale down high bids and to vote simply to show support (so dollars may be largely ignored), which may explain why the yes-response rate stays high at higher bids. On the other hand, we found people to be more neoclassical (think in terms of money trade-offs) at the high bid levels and more likely to think that the red knot funds would not be used solely for protecting the red knot. Both of these effects work to decrease yes responses at high bids. In short, we cannot say we found anything in the follow-up-question responses to "explain away" the presence of fat tails and the response to high bids.

\section{DISCUSSION}

Consider Table 1 again. Based on our findings, we are left wondering what would have happened if higher bids had been considered in many of these studies where the yes-response function is truncated. While we cannot say for sure, we suspect they may have had findings similar to ours: a difficulty pinning down the tail of the yes-response function and a mean willingness-to-pay estimate that is highly sensitive to choice of maximum bid and perhaps implausibly high at extreme bids. It would be interesting to test their surveys.

Consequentiality has become an important issue in contingent valuation (Herriges et al., 2010). In order for respondents to provide meaningful data, they need to believe that the survey is consequential and that their responses matter for policy purposes. At least two recent studies are designed to address consequentiality (Herriges et al. 2010; Petrolia et al., 2014). Both appear to have fat tails, suggesting that a lack of 
consequentiality may not be the issue. Obviously, more is needed here to draw definitive conclusions.

Again, we see fat tails as a manifestation of hypothetical bias (the tendency of people to report a value other than their true value due to the hypothetical nature of a survey) and not an isolated contingent valuation issue. Fat tails are, after all, consistent with most contingent valuation phenomena believed to cause hypothetical bias: yea-saying, anchoring, using valuation questions to express emotive instead of trade-off values, using valuation questions to show support for a program, and so on. Viewed in this way, fixing fat tails amounts to fixing the fundamental hypothetical bias presence in contingent valuation.

Truncating high-end bids is a tempting response to fat tails. If the tail of the yes-response surface is ignored over its high end, the analyst may offer truncated values using a lower-bound non-parametric estimator as a conservative value. But, this is not a real fix to the underlying problem of hypothetical bias, nor is the resulting willingness to pay truly conservative. Indeed, it "hides" the effects of fat tails. One may falsely believe that he or she has a reasonable estimate of value when in fact the survey instrument could produce vastly different values with only modest changes in the bid levels offered. Truncating offers nothing new for understanding underlying preferences, explaining why contingent valuation data yield fat tails, or dealing with hypothetical bias.

Perhaps our most startling finding is the sensitivity of mean willingness to pay to the largest bid. This is because so much of the willingness to pay is captured in the high-end tail of the yes-response function (or demand function over high prices). One can easily double or triple a mean willingness to pay by simply picking a larger bid. This lack of robustness is troubling.

We encourage more exploration into the causes and consequences of fat tails in contingent valuation response data. Follow-up questions similar to ours but perhaps more probative might shed some light on underlying behavior and intentions of respondents facing high bids. It should be kept in mind, however, that the behavioral anomalies present for people facing high bids are likely to exist for all respondents, since bids are assigned randomly. We are also interested in knowing whether there is a fat tails equivalent for choice experiments. This would manifest through sensitivity of willingness-to-pay estimates to the maximum bid level used for the payment attribute in the choice experiment. Finally, alternative behavioral models, along with tests, to better explain choice by respondents in a survey setting may lead to a better understanding of the unexpected responses we see to high bids. 


\section{REFERENCES}

Adamowicz, V., M. Dickie, S. Gerking, M. Veronesi, and D. Zinner (2014), "Household decision making and valuation of environmental health risks to parents and their children," Journal of the Association of Environmental and Resource Economists, 1(4), 481-519.

Alberini, A., B. Kanninen, and R.T. Carson (1997), "Modeling response incentive effects in dichotomous choice contingent valuation data," Land Economics, 73(3), 309-24.

Andersson, H., J. Hammitt, G. Lindberg, and K. Sundström (2013), "Willingness to pay and sensitivity to time framing: A theoretical analysis and application on car safety," Environmental and Resource Economics, 56(3), 437-56.

Balistreri, E., G. McClelland, G. Poe, and W. Schulze (2001), "Can hypothetical questions reveal true values? A laboratory comparison of dichotomous choice and open-ended contingent values with auction values," Environmental and Resource Economics, 18(3), 275-92.

Banzhaf, H.S., D. Burtraw, D. Evans, and A. Krupnick (2006), "Valuation of natural resource improvements in the Adirondacks," Land Economics, 82(3), 445-64.

Berrens, R.P., A.K. Bohara, and J. Kerkvliet (1997), "A randomized response approach to dichotomous choice contingent valuation," American Journal of Agricultural Economics, 79(1), 252-66.

Berrens, R.P., P. Ganderton, and C.L. Silva (1996), "Valuing the protection of minimum instream flows in New Mexico," Journal of Agricultural and Resource Economics, 21(2), 294-308.

Blamey, R.K., J.W. Bennett, and M.D. Morrison (1999), "Yea-saying in contingent valuation surveys," Land Economics, 75(1), 126-41.

Blomquist, G.C., K. Blumenschein, and M. Johannesson (2009), "Eliciting willingness to pay without bias using follow-up certainty statements: Comparisons between probably/definitely and a 10-point certainty scale," Environmental and Resource Economics, 43(4), 473-502.

Boman, M., G. Bostedt, and B. Kriström (1999), "Obtaining welfare bounds in discrete-response valuation studies: A non-parametric approach," Land Economics, 75(2), 284-94.

Boyle, K.J. (2003), "Contingent valuation in practice," in P.A. Champ, K.J. Boyle, and T.C. Brown (eds), A Primer on Nonmarket Valuation, Dordrecht: Kluwer Academic Publishers, pp. 111-69.

Brown, T.C., I. Ajzen, and D. Hrubes (2003), "Further tests of entreaties to avoid hypothetical bias in referendum contingent valuation," Journal of Environmental Economics and Management, 46(2), 353-61.

Brown, T.C., P.A. Champ, R.C. Bishop, and D.W. McCollum (1996), "Which response format reveals the truth about donations to a public good?," Land Economics, 72(2), 152-66.

Cameron, T.A. and J. Quiggin (1994), "Estimation using contingent valuation data from a 'dichotomous choice with follow-up' questionnaire," Journal of Environmental Economics and Management, 27(3), 218-34.

Carson, R.T., R.C. Mitchell, M. Hanemann, R.J. Kopp, S. Presser, and P.A. Ruud (2003), "Contingent valuation and lost passive use: Damages from the Exxon Valdez oil spill," Environmental and Resource Economics, 25(3), 257-86. 
Carson, R.T., W.M. Hanemann, R.J. Kopp, J.A. Krosnick, R.C. Mitchell, S. Presser, P.A. Ruud, and V.K. Smith (1994), Prospective Interim Lost Use Value Due to DDT and PCB Contamination in the Southern California Bight, report prepared for the National Oceanic and Atmospheric Administration, La Jolla, CA: Natural Resource Damage Assessment, Inc.

Champ, P.A. and R.C. Bishop (2001), "Donation payment mechanisms and contingent valuation: An empirical study of hypothetical bias," Environmental and Resource Economics, 19(4), 383-402.

Champ, P.A. and R.C. Bishop (2006), "Is willingness to pay for a public good sensitive to the elicitation format?," Land Economics, 82(2), 162-73.

Champ, P.A., R. Moore, and R.C. Bishop (2009), "A comparison of approaches to mitigate hypothetical bias," Agricultural and Resource Economics Review, 38(2), 166-80.

Champ, P.A., R.C. Bishop, T.C. Brown, and D.W. McCollum (1997), "Using donation mechanisms to value nonuse benefits from public good," Journal of Environmental Economics and Management, 33(2), 151-62.

Champ, P.A., N. Flores, T. Brown, and J. Chivers (2002), "Contingent valuation and incentives," Land Economics, 78(4), 591-604.

Chien, Y., C. Huang, and D. Shaw (2005), "A general model of starting point bias in double-bounded dichotomous contingent valuation surveys," Journal of Environmental Economics and Management, 52(2), 362-77.

Cook, J., M. Jeuland, B. Maskery, and D. Whittington (2012), "Giving stated preference respondents 'time to think': Results from four countries," Environmental and Resource Economics, 51(4), 473-96.

Cooper, J. and J. Loomis (1992), "Sensitivity of willingness-to-pay estimates to bid design in dichotomous choice contingent valuation models," Land Economics, 68(2), 211-24.

Corrigan, J., C. Kling, and J. Zhao (2008), "Willingness to pay and the cost of commitment: An empirical specification and test," Environmental and Resource Economics, 40(2), 285-98.

Desvousges, W.H., K. Mathews, and K. Train (2015), "An adding-up test on contingent valuations of river and lake quality," Land Economics, 91(3), 556-71.

Desvousges, W.H., F.W. Johnson, R.W. Dunford, S.P. Hudson, K.N. Wilson, and K.J. Boyle (1993), 'Measuring natural resource damages with contingent valuation: Tests of validity and reliability', in J.A. Hausman (ed.), Contingent Valuation: A Critical Assessment, Amsterdam: Elsevier Science, pp. 91-164.

Egan, K., J. Corrigan, and D. Dwyer (2015), "Three reasons to use annual payments in contingent valuation surveys: Convergent validity, discount rates, and mental accounting," Journal of Environmental Economics and Management, 75, 123-36.

Farmer, M. and C. Lipscomb (2008), "Conservative dichotomous choice responses in the active policy setting: DC rejections below WTP," Environmental and Resource Economics, 39(3), 223-46.

Frykblom, P. (1997), "Hypothetical question modes and real willingness to pay," Journal of Environmental Economics and Management, 34(3), 275-87.

Frykblom, P. and J.F. Shogren (2000), "An experimental testing of anchoring effects in discrete choice questions," Environmental and Resource Economics, 16(3), 329-41.

Gerking, S., M. Dickie, and M. Veronesi (2014), "Valuation of human health: An 
integrated model of willingness to pay for mortality and morbidity reductions," Journal of Environmental Economics and Management, 68(1), 20-45.

Giraud, K.L., C.A. Bond, and J.J. Bond (2005), "Consumer preferences for locally made specialty food products across northern New England," Agricultural and Resource Economics Review, 34(2), 204-16.

Giraud, K.L., J.B. Loomis, and J.C. Cooper (2001), "A comparison of willingnessto-pay estimation techniques from referendum questions," Environmental and Resource Economics, 20(4), 331-46.

Guria, J., J. Leung, M. Jones-Lee, and G. Loomes (2005), “The willingness to accept value of statistical life relative to the willingness to pay value: Evidence and policy implications," Environmental and Resource Economics, 32(1), 113-27.

Haab, T.C. and K.E. McConnell (1997), "Referendum models and negative willingness to pay: Alternative solutions," Journal of Environmental Economics and Management, 32(2), 251-70.

Haab, T.C. and K.E. McConnell (1998), "Referendum models and economic values: Theoretical, intuitive, and practical bounds on willingness to pay," Land Economics, 74(2), 216-29.

Haab, T.C. and K.E. McConnell (2002), Valuing Environmental and Natural Resources, Cheltenham, UK and Northampton, MA, USA: Edward Elgar Publishing.

Hammitt, J.K. and Y. Zhou (2006), "The economic value of air-pollution-related health risks in China: A contingent valuation study," Environmental and Resource Economics, 33(3), 399-423.

Harrison, G.W. and J.C. Lesley (1996), "Must contingent valuation surveys cost so much?," Journal of Environmental Economics and Management, 31(1), 79-95.

Herriges, J., C. Kling, C. Liu, and J. Tobias (2010), "What are the consequences of consequentiality?," Journal of Environmental Economics and Management, 59(1), $67-81$.

Hite, D., D. Hudson, and W. Intarapapong (2002), "Willingness to pay for water quality improvements: The case of precision application technology," Journal of Agricultural and Resource Economics, 27(2), 433-49.

Holmes, T.P. and R.A. Kramer (1995), "An independent sample test of yea-saying and starting point bias in dichotomous-choice contingent valuation," Journal of Environmental Economics and Management, 29(1), 121-32.

Huth, W.L. and O.A. Morgan (2011), "Measuring the willingness to pay for cave diving," Marine Resource Economics, 26(2), 151-66.

Ivehammar, P. (2009), "The payment vehicle used in CV studies of environmental goods does matter," Journal of Agricultural and Resource Economics, 34(3), 450-63.

Johnston, R.J. (2006), "Is hypothetical bias universal? Validating contingent valuation responses using a binding public referendum," Journal of Environmental Economics and Management, 52(1), 469-81.

Kanninen, B.J. (1993), "Bias in discrete response contingent valuation," Journal of Environmental Economics and Management, 28(1), 114-25.

Kanninen, B. and B. Kriström (1993), "Sensitivity of willingness to pay estimates to bid design in dichotomous choice valuation models: Comment," Land Economics, 69(2), 199-202.

Koford, B., G. Blomquist, D. Hardesty, and D. Troske (2012), "Estimating consumer willingness to supply and willingness-to-pay for curbside recycling," Land Economics, 88(4), 745-63. 
Kovacs, K.F. and D.M. Larson (2008), "Identifying individual discount rates and valuing public open space with stated-preference models," Land Economics, 84(2), 209-24.

Kramer, A. and D. Evan Mercer (1997), "Valuing a global environmental good: U.S. residents' willingness to pay to protect tropical rain forests," Land Economics, 73(2), 196-210.

Kriström, B. (1990), "A non-parametric approach to the estimation of welfare measures in discrete response valuation studies," Land Economics, 66(2), $135-9$.

Labao, R., H. Francisco, D. Harder, and F.I. Santos (2008), "Do colored photographs affect willingness-to-pay responses for endangered species conservation?," Environmental and Resource Economics, 40(2), 251-64.

Landry, C.E. and J.A. List (2007), "Using ex ante approaches to obtain credible signals for value in contingent markets: Evidence from the field," American Journal of Agricultural Economics, 89(2), 420-29.

Langford, I., I. Bateman, A. Jones, H. Langford, and S. Georgiou (1998), "Improved estimation of willingness-to-pay in dichotomous choice contingent valuation studies," Land Economics, 74(1), 65-75.

Leiter, A.M. and G.J. Pruckner (2009), "Proportionality of willingness-to-pay to small changes in risk: The impact of attitudinal factors in scope tests," Environmental and Resource Economics, 42(2), 169-86.

Leon, C. and J. Arana (2012), "The dynamics of preference elicitation after an environmental disaster: Stability and emotional load," Land Economics, 88(2), $362-81$.

Lindberg, K., R.L. Johnson, and R.P. Berrens (1997), "Contingent valuation of rural tourism development with tests of scope and mode stability," Journal of Agricultural and Resource Economics, 22(1), 44-60.

Longo, A., D. Hoyos, and A. Markandya (2012), "Willingness to pay for ancillary benefits of climate change mitigation," Environmental and Resource Economics, 51(1), 119-40.

Longo, A., D. Hoyos, and A. Markandya (2015), "Sequence effects in the valuation of multiple environmental programs using the contingent valuation method," Land Economics, 91(1), 20-35.

Loureiro, M.L., J.B. Loomis, and M.X. Vázquez (2009), "Economic valuation of environmental damages due to the Prestige oil spill in Spain," Environmental and Resource Economics, 44(4), 537-53.

Lunander, A. (1998), "Inducing incentives to understate and to overstate willingness-to-pay within the open-ended and the dichotomous-choice elicitation formats: An experimental study," Journal of Environmental Economics and Management, 35(1), 88-102.

Lusk, J.L. (2003), "Effects of cheap talk on consumer willingness-to-pay for golden rice," American Journal of Agricultural Economics, 85(4), 840-56.

McFadden, D. and G.K. Leonard (1993), "Issues in the contingent valuation of environmental goods: Methodologies for data collection and analysis," in J.A. Hausman (ed.), Contingent Valuation: A Critical Assessment, Amsterdam: Elsevier Science, pp. 165-216.

Michael, J.A. and S.D. Reiling (1997), "The role of expectations and heterogeneous preferences for congestion in the valuation of recreation benefits," Agricultural and Resource Economics Review, 26(2), 166-73.

Moore, R., B. Provencher, and R.C. Bishop (2011), "Valuing a spatially variable 
environmental resource: Reducing non-point-source pollution in Green Bay, Wisconsin," Land Economics, 87(1), 45-59.

Morgenstern, R., W. Pizer, and J. Shih (1998), "The cost of environmental protection," Resources for the Future Discussion Paper No. 98-36.

Morrison, M. and T. Brown (2009), "Testing the effectiveness of certainty scales, cheap talk, and dissonance-minimization in reducing hypothetical bias in contingent valuation studies," Environmental and Resource Economics, 44(3), 307-26.

Murphy, J.J., T.H. Stevens, and D. Weatherhead (2005), "Is cheap talk effective at eliminating hypothetical bias in a provision point mechanism?," Environmental and Resource Economics, 30(3), 327-43.

Myers, K.H., G.R. Parsons, and P.E. Edwards (2010), "Measuring the recreational use value of migratory shorebirds on the Delaware Bay," Marine Resource Economics, 25(3), 247-64.

Nahuelhual, L., M.L. Loureiro, and J. Loomis (2004), "Using random parameters to account for heterogeneous preference in contingent valuation of public open space," Journal of Agricultural and Resource Economics, 29(3), 537-52.

Nunes, P. and J. van den Bergh (2004), "Can people value protection against invasive marine species? Evidence from a joint TC-CV survey in the Netherlands," Environmental and Resource Economics, 28(4), 517-32.

Petrolia, D. and T. Kim (2009), "What are Barrier Islands worth? Estimated of willingness to pay for restoration," Marine Resource Economics, 24(2), 131-46.

Petrolia, D., M. Interis, and J. Hwang (2014), "America's wetland? A national survey of willingness-to-pay for restoration of Louisiana's coastal wetlands," Marine Resource Economics, 29(1), 17-37.

Polome, P., A. Veen, and P. Geurts (2006), "Is referendum the same as dichotomous choice contingent valuation?," Land Economics, 82(2), 174-88.

Poor, P.J. (1999), "The value of additional central flyway wetlands: The case of Nebraska's rainwater basin wetlands," Journal of Agricultural and Resource Economics, 24(1), 253-65.

Popp, D. (2001), "Altruism and the demand for environmental quality," Land Economics, 77(3), 339-49.

Ready, R.C. and D. Hu (1995), "Statistical approaches to the fat tail problem for dichotomous choice contingent valuation," Land Economics, 71(4), 491-9.

Ready, R.C., J.C. Buzby, and D. Hu (1996), "Difference between continuous and discrete contingent value estimates," Land Economics, 72(3), 397-411.

Reaves, D.W., R.A. Kramer, and T.P. Holmes (1999), "Does question format matter? Valuing an endangered species," Environmental and Resource Economics, 14(3), 365-83.

Richardson, L., J. Loomis, and P. Champ (2013), "Valuing morbidity from wildfire smoke exposure: A comparison of revealed and stated preference techniques," Land Economics, 89(1), 76-100.

Riddel, M. and J. Loomis (1998), "Joint estimation of multiple CVM scenarios under a double bounded questioning format," Environmental and Resource Economics, 12(1), 77-98.

Roach, B., K.J. Boyle, and M. Welsh (2002), "Testing bid design effects in multiplebounded, contingent-valuation questions," Land Economics, 78(1), 121-31.

Ropicki, A.J., S.L. Larkin, and C.M. Adams (2010), "Seafood substitution and mislabeling: WTP for a locally caught grouper labeling program in Florida," Marine Resource Economics, 25(1), 77-92.

Saz-Salazar, S. and L. Garcia-Menendez (2001), "Willingness to pay for 
environmental improvements in a large city," Environmental and Resource Economics, 20(2), 103-12.

Scarpa, R., K. Willis, and G. Garrod (2001), "Estimating benefits for effective enforcement of speed reduction from dichotomous-choice CV," Environmental and Resource Economics, 20(4), 281-304.

Smith, V.K. (1996), "Can contingent valuation distinguish economic values for different public goods?," Land Economics, 72(2), 139-51.

Tuan, T.R. and S. Navrud (2007), "Valuing cultural heritage in developing countries: Comparing and pooling contingent valuation and choice modeling estimates," Environmental and Resource Economics, 38(1), 51-69.

Vaughan, W.J. and D.J. Rodriguez (2001), "Obtaining welfare bounds in discreteresponse valuation studies: Comment," Land Economics, 77(3), 457-65.

Wang, H. (1997), “Treatment of 'don't-know' responses in contingent valuation surveys: A random valuation model," Journal of Environmental Economics and Management, 32(2), 219-32.

Weldesilassie, A.B., O. Frör, E. Boelee, and S. Dabbert (2009), "The economic value of improved wastewater irrigation: A contingent valuation study in Addis Ababa, Ethiopia," Journal of Agricultural and Resource Economics, 34(3), 428-49.

Welsh, M.P. and G.L. Poe (1998), "Elicitation effects in contingent valuation: Comparisons to a multiple bounded discrete choice approach," Journal of Environmental Economics and Management, 36(2), 170-85.

Whitehead, J. (2002), "Incentive compatibility and starting-point bias in iterative valuation questions," Land Economics, 78(2), 285-97.

Whitehead, J., W.B. Clifford, and T.J. Hoban (2001), "Willingness to pay for a saltwater recreational fishing license: A comparison of angler groups," Marine Resource Economics, 16(3), 177-94.

Whittington, D. (2002), "Improving the performance of contingent valuation studies in developing countries," Environmental and Resource Economics, 22(2), 323-67.

Zhang, H., K. Gallardo, J. McCluskey, and E. Kupferman (2010), "Consumers' willingness-to-pay for treatment-induced quality attributes in Anjou pears," Journal of Agricultural and Resource Economics, 35(1), 105-17. 